\title{
Atypical Presentation of Herpes Simplex 1 Virus in a COVID-19 Patient
}

\section{Apresentação Atípica de Herpes Virus 1 num Doente COVID-19}

Received/Recebido $2021 / 05 / 16$

Accepted/Aceite 2021/08/13 $2021 / 12 / 30$

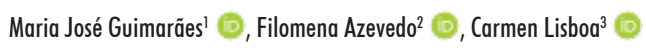

'Department of Dermatology and Venereology, Hospital de Braga, EPE, Braga, Portugal

${ }_{2}^{2}$ Department of Dermatology and Venereology, Centro Hospitalar Universitário S. João, Porto, Portugal

${ }^{3}$ Department of Dermatology and Venereology, Centro Hospitalar Universitário S. João, Porto, Portugal; Division of Microbiology, Department of Pathology, Faculty of Medicine,

University of Porto, Porto, Portugal

KEYWORDS - COVID-19; Herpesvirus 1, Human.

PALAVRAS-CHAVE - COVID-19; Herpesvirus Humano 1.

\section{CASE REPORT}

A 74-year-old man with past medical history of obesity and type 2 diabetes mellitus was admitted for COVID-19 pneumonia. Due to unfavorable disease progression, ten days later, the patient was admitted to the intensive care unit and intubated, requiring periods of prone position and systemic corticosteroid treatment. During the following weeks, the patient developed several infectious complications successfully managed with systemic antibiotics and herpes simplex infection of the left upper lip, treated with acyclovir $400 \mathrm{mg}$ twice daily for 10 days.

Dermatology observation was requested 2 days after acyclovir cessation due to an infiltrative hyperkeratotic erythematous plaque with pustules on the right zygomatic region (see picture 1) that had been noticed 2 days before.

Polymerase chain reaction (PCR)-testing of swab samples from the pustules was positive for herpes simplex virus (HSV) 1, with negativity for HSV 2 and for varicella-zoster virus (VZV). Blood and CSF fluid PCR were negative for HSV 1, HSV 2 and VZV. The patient restarted acyclovir (400 mg, thrice daily for 12 days) with significant improvement of the lesion (less infiltration and hyperkeratotic crusts) and negative PCR-testing for HSVI DNA after treatment cessation (see picture 2). About 2 weeks later the lesion was completely healed leaving a minor atrophic scar.

\section{DISCUSSION}

Based on the clinical picture and PCR results, the diagnosis is recurrence of HSV 1. This is an atypical manifestation of HSV with a hyperkeratotic sycosis-like facial plaque. Atypical manifestations of HSV are rare and occur predominantly in immunocompromised patients - namely among human immunodeficiency virus (HIV)-positive patients, transplant recipients, those suffering from hematological

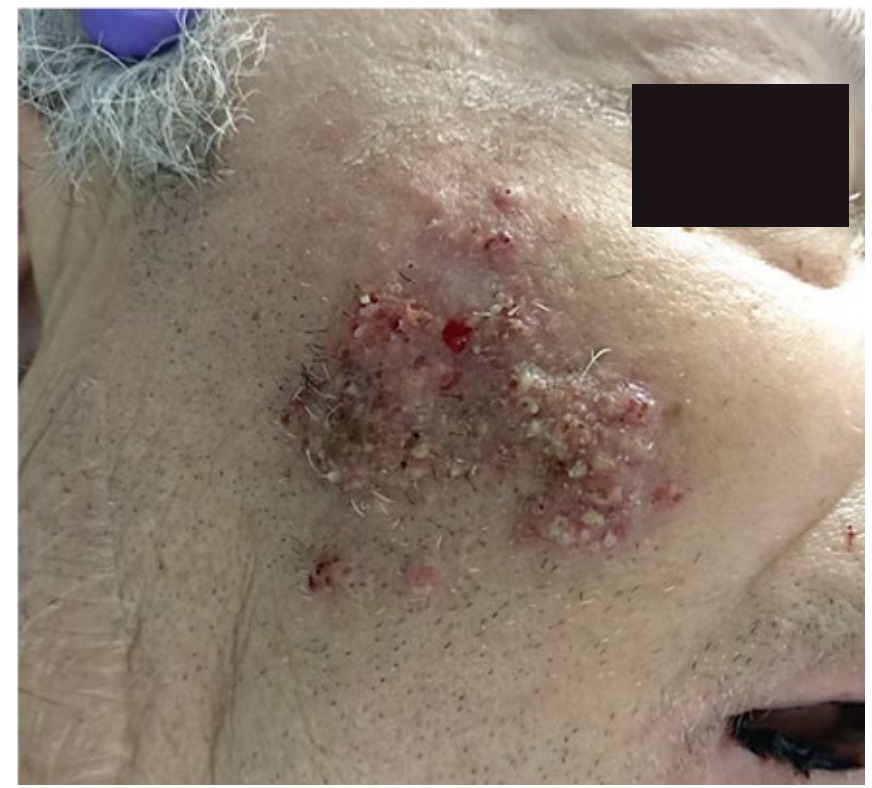

Figure 1 - Infiltrative hyperkeratotic erythematous plaque with pustules on the right zygomatic region at first evaluation.

diseases or under systemic corticosteroids. ${ }^{1}$ The classical picture of HSV 1 infection, characterized by small, grouped vesicles in an erythematous base, can be absent in these situations.' Occasionally, these patients present with uncommon manifestations, such as hypertrophic, verrucous lesions, tissue necrosis, chronic ulcers, folliculitis or sycosis-like lesions. ${ }^{1,2}$ Whilst hypertrophic manifestations are well described in HSV 2 genital infections, they are extremely rare in HSV 1 infections. ${ }^{3}$

In this patient, we believe the severe COVID-19 disease together 


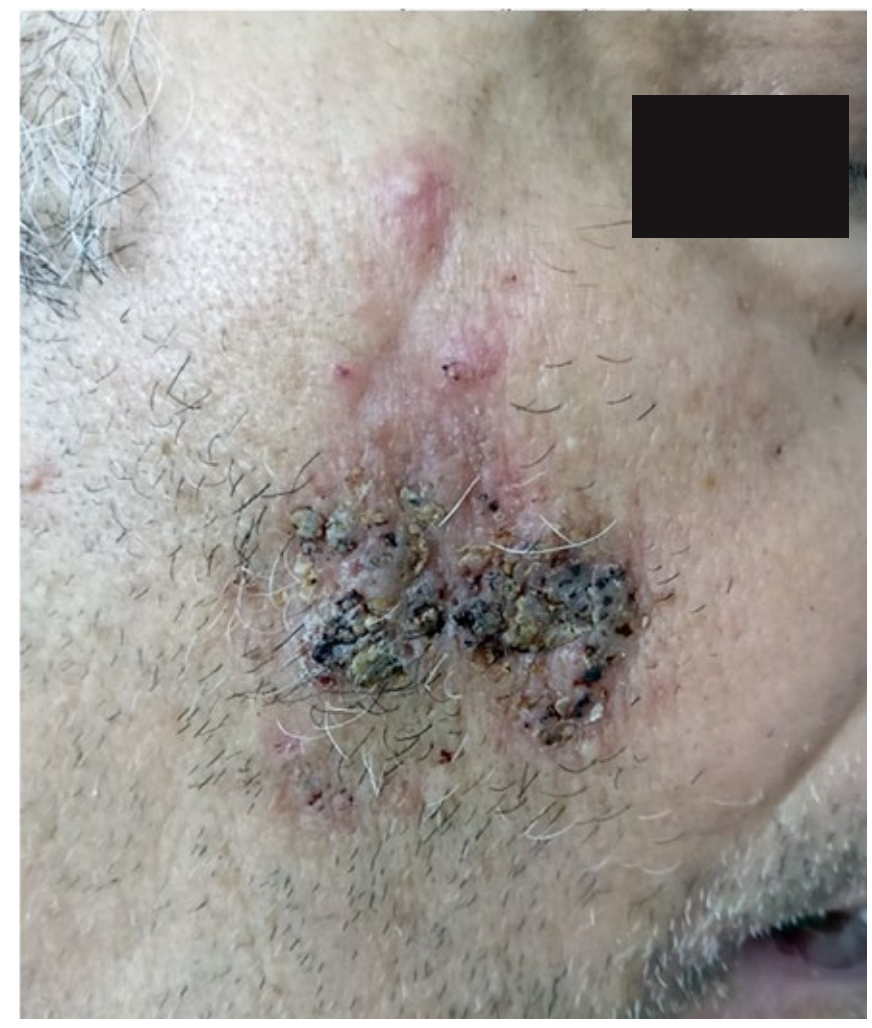

Figure 2 - Plaque with less infiltration and with hyperkeratotic crusts 12 days after treatment initiation.

with the prolonged course of corticosteroids and the short and underdosed initial course of acyclovir enabled the development of this atypical lesion, explained recurrence immediately after suspension of the antiviral drug. In a case series reporting five cases of HSV 1 keratitis in COVID-19 patients, the authors postulated that the decline in NK cells and CD8 + T cells found in SARS-CoV-2 infections could play a role in potentiating the reactivation of HSV $1 .{ }^{4}$

In immunocompromised patients, HSV infection is generally more severe, presenting with extensive lesions and increased resistance to standard therapeutic regimens. ${ }^{5}$ Combination of acyclovir with an immunomodulator such as topical imiquimod can be an alternative regimen in more recalcitrant cases. ${ }^{5}$

Atypical manifestations of HSV infection raise diagnostic challenges and sometimes lead to treatment delays. ${ }^{4}$ Any hyperkeratotic, ulcerated or folliculitis-like lesion in an immunocompromised patient should raise a high index of suspicion for herpes infection that can be confirmed by PCR-testing. In these high-risk patients, treatment duration should be increased until complete lesion resolution. ${ }^{4}$

Conflicts of Interest: The authors have no conflicts of interest to declare. Financing Support: This work has not received any contribution, grant or scholarship. Confidentiality of Data: The authors declare that they have followed the protocols of their work center on the publication of data from patients. Patient Consent: Consent for publication was obtained. Provenance and Peer Review: Not commissioned; externally peer reviewed.

Conflitos de Interesse: Os autores declaram a inexistência de conflitos de interesse na realização do presente trabalho. Fontes de Financiamento: Não existiram fontes externas de financiamento para a realização deste artigo. Confidencialidade dos Dados: Os autores declaram ter seguido os protocolos da sua instituição acerca da publicação dos dados de doentes. Consentimento: Consentimento do doente para publicação obtido. Proveniência e Revisão por Pares: Não comissionado; revisão externa por pares.

\section{ORCID}

Maria José Guimarães: https://orcid.org/0000-0002-3247-2470

Filomena Azevedo: https://orcid.org/0000-0003-0402-6382

Carmen Lisboa: https://orcid.org/0000-0001-8247-8902

Corresponding Author: Maria José Guimarães

Address: Hospital de Braga, EPE, Sete Fontes - São Victor, 4710-243 Braga, Portugal

E-mail: mjcunhaguimaraesgmail.com

(C) Author(s) (or their employer(s)) 2021 SPDV Journal. Re-use permitted under CC BY-NC. No commercial re-use.

(c) Autor (es) (ou seu (s) empregador (es)) 2021 Revista SPDV. Reutilização permitida de acordo com CC BY-NC. Nenhuma reutilização comercial.

\section{REFERENCES}

1. Garrido PM, Borges-Costa J. Manifestações clínicas atípicas de infeção genital pelos vírus herpes simplex e sua abordagem terapêutica. J Port Soc Dermatol Venereol. 2018;76:65-70.

2. Ogawa $Y$, Higuchi $T$, Koyamada R, Arai $S$, Okada S. Hypertrophic herpes simplex virus type 1 infection in a patient with acute myeloid leukemia. J Hematol. 2017;6:68-71. doi: 10.14740/ih333w.

3. Majtanova N, Kriskova P, Keri P, Fellner Z, Maitan J, Kolar P. Herpes simplex keratitis in patients with SARS-CoV-2 infection: a series of five cases. Medicina. 2021;57:412. doi: 10.3390/medicina57050412.

4. Tyring S, Carlton S, Evans T. Herpes. Atypical clinical manifestations. Dermatol Clin. 1998;16:783-8.

5. Sbidian E, Battistella M, LeGoff J, Lafaurie M, Bézier M, Agbalika F, et al. Recalcitrant pseudotumoral anogenital herpes simplex virus type 2 in HIV-infected patients: evidence for predominant B-lymphoplasmocytic infiltration and immunomodulators as effective therapeutic strategy. Clin Infect Dis.2013;57:1648-55. doi: 10.1093/cid/cit592. 